\title{
HLAS A GESTO V OPERÁCH HARRYHO PARTCHA A JOHNA ZORNA
}

Vznik a vývoj elektronickej hudby v 20. storočí okrem iného spôsobil, že dokonale zintegrovaný hlas rezignoval na archetypálnu čistotu orály ako vehikula emocionality a asimiloval v reverzibilnom rituáli inštrumentálnej vokalýzy. Netrvalo však dlho a nezainteresované ,znejúce súcna“ nadobudli reprezentačné, či dokonca demiurgické ambície. Dezintegrácia posvätného hlasu na diseminované hlasy spôsobila echolalický efekt: autentická výpoved' hlasu o svete zanikla vo vlastných ozvenách a do-zvukoch, ktoré ju nielen pre-hlušili ale aj pre-vraveli, ked' r. 1969 nechal Alvin Lucier rozplynút' vlastný hlas vo vibrujúcich rezonanciách prostredia potom, čo ho hlas sám rozozvučal. Autorov hlas sa zmenil na anonymný hlas; z parole sa zrazu stal langue - vokálna matéria, z ktorej možno tkat' texty. Slovo stvorilo hudbu z ničoho - iba tým, že jednoducho rozprávalo, čo a ako práve tvorí. Významové zhluky hlások sa samovol'ne pretransformovali na tónové motívy bez fixovaných konotácií, zo slov a viet sa stali melodické frázy. Autor sa nenápadne vytratil zo scény a sublimoval do neosobnej, či skôr nadosobnej zvukovej matérie. Magneticky odcudzený hlas rozdvojil a d'alej multiplikoval autora, až ho celkom pohltila ozvena miestnosti. Do hry vstúpil priestor, ktorý tu „, funguje ako filter; odfiltrováva všetky frekvencie okrem tých, čo rezonujú. Má to dočinenia s architektúrou, fyzikálnymi rozmermi a akustickými vlastnost'ami priestoru. [...] Opakovaným prehrávaním zvukov do miestnosti niektoré z nich väčšmi a väčšmi zosilňujete a iné eliminujete. Je to forma amplifikácie prostredníctvom repetície. To, že som začal o zvukoch premýšl'at' ako o meratel'ných vlnových dízkach a nie ako o vysokých a nízkych hudobných tónoch, zmenilo celé moje chápanie hudby, už nie ako metafory ale ako faktu, a doslova ma spojilo s architektúrou."1

Lucier v legendárnom kuse I Am Sitting in a Room navyše odhalil, že hlas je neoddelitel'ný od fyzického gesta, od ktorého ho stáročia izolovali hudobné poetiky i praktiky, vzd'al'ujúce prirodzenú zvukotvorbu a amatérske muzicírovanie pôvodným spôsobom a princípom sebavyjadrenia. Jeho performačné gesto ale

1 LUCIER, Alvin. Reflections/Reflexionen. Kolín nad Rýnom: MusikTexte, 1995, s. 95-98. 
nemalo nič spoločné s „elektronickým gestom“ Iannisa Xenakisa, pretože ten sa snažil ovládnut' priestor prostredníctvom komplexnej „umeleckej syntézy zvuku, svetla a architektúry “, ${ }^{2}$ kde pre telesnost' a bezprostrednú expresivitu nebolo miesta. No a následné dekonštruktívne praktiky v umení i humanitnom vedení v plnej miere ukázali, že oddelit' hlas od gesta je nielen kontraproduktívne, ale aj prakticky nemožné. Skrátka, nastal vhodný čas, aby gesto pripomenulo hlasu, že nielen že nie je jediným prirodzeným vyjadrovacím prostriedkom hudby, ale že aj ono stálo pri zrode antického princípu mimézis. ${ }^{13}$

Harry Partch reflektoval prirodzenú spätost' hlasu a gesta v koncepte „korporeálnej hudby“, ktorú odlíšil od jej súvekej „abstraktnej“ súperky. Zatial’ čo historicky mladšia abstraktná hudba neprirodzene lipne na konvencionalizovaných náladových, štylistických, manieristických a inštrumentálnych praktikách a poetických floskulách na úkor významových posolstiev, korporeálna hudba, príznačná pre l’udovú piesňovú tvorbu, náboženské obrady, ranú európsku operu, hudobnú drámu a scénickú hudbu, sa manifestuje v integrovanej fúzii poézie so zvukovou a dramatickou akciou. Partch preto kladie korporeálnu hudbu na roveň s rituálom a zdôrazňuje jej spektakulárnost' a významovost'; je to hudba závislá od významu slova, zvuku nástroja i tela hlasu.

Partch priviedol svoju víziu korporeálnej hudby $\mathrm{k}$ vrcholu v scénickom intermédiu Delusion of the Fury (Prelud zúrivosti; 1965). V úvode libreta vyhlásil: „Slová nedokážu nahradit' skúsenost' poznania - videnia a počutia. Koncept tohto diela spočiva $v$ pritomnosti nástrojov na scéne, pohyboch hudobníkov a zboru, zvukoch, ktoré produkujú, skutočnosti hercov, spevákov, mímov, svetiel, teda $v$ skutočnosti naozaj integrovaného divadla. [...] Domnievam sa, že jedinýspôsob, ako zistit' [jeho] autentickú integritu, je vidiet' a počut' predstavenie. "“4 Dielo síce obsahuje vokálne party, no drvivá väčšina z nich je bez slov a len niektoré slová dávajú sémantický zmysel (v angličtine). Napriek tomu je úloha zboru vel'mi dôležitá, dokonca dejotvorná. Hlasy nespievajú, ale účinkujú spolu s inštrumentálnymi zvukmi, pohybmi a gestami aktérov, ktorí berú na seba striedavo alebo súčasne role hudobníkov, vokalistov, hercov, mímov a tanečníkov. Je to skutočná hudba v akcii, rituál sprítomňujúci nadčasovú víziu skladatel'a v slede koordinovaných performancií, rozvrhnutých do dvoch dejstiev a inscenovaných v dvoch rozdielnych kultúrnych kontextoch. Obidve časti sa líšia aj stvárnením mýtického archetypu duality života a smrti. Zatial' čo prvá, inšpirovaná japonskou drámou Nó, reprezentuje zmierenie sa života so smrt’ou, druhá, inšpirovaná etiópskou l'udovou povest'ou, reprezentuje zmierenie sa smrti s existenciou života. Hrdinom prvého príbehu je padlý bojovník vznešeného pôvodu, ktorý, už ako duch,

2 XENAKIS, Iannis. Poznámky o elektronickom geste. Slovenský preklad: Vladimír Godár. Slovenská hudba, 1993, 1, s. 48-50.

3 Skôr než sa zaužíval v reflexii výtvarných umenia, princíp mimézis bol vyhradený pre múzické umenia, kde sa ním označovalo napodobňovanie pohybom, gestom, hlasom.

$4 \quad$ PARTCH, Harry. Bitter Music. Collected Journals, Essays, Introductions, and Librettos. Urbana/Chicago: University of Illinois Press, 2000, s. 445. 
stretáva svojho posmrtne narodeného syna, dramatické napätie druhého príbehu je vystavané na komunikačnom nedorozumení medzi mladým hluchým tulákom a starou pastierkou, ktorá hl'adá zatúlané kozl'a. Obidve dejstvá končia rovnakou zborovou modlitbou a prepája ich krátke interlúdium Sanctus.

Každé dejstvo má svojho principála; môže ním byt' hudobník, herec, mím alebo tanečník, musí však byt' hudobne vzdelaný, aby bol schopný integrovat' „odtelesnený hlas" svojho partu do komplexnej scénickej akcie a prispiet' k nej hudobne, pohybovo i gesticky. Integrálnou súčast’ou scény sú Partchove nekonvenčné, vlastnoručne vyrobené hudobné nástroje podla dizajnu, vychádzajúceho zo skladatel'ovho dlhoročného intenzívneho štúdia mikrotonality a neeurópskych tónin. Okrem primárnej hudobnej funkcie majú tiež dôležitý scénografický zmysel, preto skladatel' venoval zvýšenú pozornost' ich vhodnému umiestneniu na scéne a podmienil nimi aj choreografické riešenie. Neváhal pritom spojit’ pragmatizmus lévi-straussovského brikoléra s akustickou funkciou i estetickou predstavou vizuálnej krásy. Podl’a spôsobu generovania zvuku sú nástroje rozdelené do troch skupín: perkusívne, brnkacie strunové, s držaným tónom a ručné nástroje členov zboru.

Samotná hudba je síce vel'korysá čo do tektoniky i sonoristiky, no vzhl’adom na originálne konštrukčné a akustické danosti nástrojov a intermediálne prepojenie s d’alšími zložkami predstavenia je interpretačne vel'mi náročná. V scénickom výsledku však dielo presvedčivo reprezentuje magickú spiritualitu rituálu. Jeho aktéri, naplňujúci rôzne profesijné i psychologické úlohy, sa kolektívne a interaktívne podiel'ajú na strhujúcej akcii, stmel'ujúcej zvuky, slová, gestá, pohyby a obrazy v „rituáli o sne a prelude,“ ako dielo charakterizuje sám jeho podtitul. Partchovi sa v Delusion of the Fury podarilo preklenút' tonálne a interpretačné obmedzenia západnej hudby a vytvorit’ novú múzickú formu, spochybňujúcu temperovaný tónový systém i interpretačné konvencie. Vd’aka vlastným invenčným hudobným nástrojom s ladeniami vychádzajúcimi z čistej intonácie a scénickým akciám, inšpirovaným archaickými mimoeurópskymi rituálmi, dokonale naplnil proklamovaný koncept korporeálnej hudby. Jednotlivých účinkujúcich i celý zbor (zoskupenie pútnikov a duchov, nazvané „Chór tieňov“) poňal ako interagujúcich nositel’ov kryptickej významovosti a zároveň epifánnej emocionality. Poučený dôsledným štúdiom antických a orientálnych hudobných a divadelných poetík, dosiahol integrovanú syntézu múzických výrazových prostriedkov, avšak nepreberal ani nekopíroval známe historické formy; na jeho poetiku mali skôr formálny vplyv. A tak, hoci si pre prvé dejstvo Delusion of the Fury vybral ako predlohu dve známe hry divadla Nó, ${ }^{5}$ sám použil úplne odlišné inštrumentálne a vokálne praktiky, tóniny i scénografické prvky, než s akými pracujú autori v hrách Nó. Výrazný rozdiel je aj v metro-rytmike: zatial' čo Partchova hudba je strhujúco metrická, hudobníci sprevádzajúci hry Nó nehrávajú podl'a pravidelných či vytrvalých metier. Väčšmi než hudbu Preludu, dráma Nó ovplyvnila jeho dramatickú štruktúru. Na rozdiel od striktnej hierarchie charakterov Nó však

Zeami Motokijo: Acumori a Zembo Motoyasu: Ikuta. 
niektorí Partchovi hrdinovia (syn, pastierka) vzdorujú tradičným charakterovým konvenciám, pretože súčasne stvárňujú rozdielne identity a reprezentujú rozdielne archetypy. Bolo by síce možné analyzovat' ich vzájomné vzt’ahy a interakcie podla štrukturalistických modelov, ako to urobili niektorí bádatelia, bola by to však kontraproduktívna interpretačná stratégia, pretože Partchova „korporeálna“ hudba nie je odvodená z vykonštruovaných modelov reality, ale priamo angažuje neprenosnú životnú skúsenost' autora, ktorá do umeleckého diela projektuje mystický aspekt. Harry Partch dokázal v Delusion of the Fury obdivuhodne skíbit' osvojené teoretické znalosti s intuíciou, odvahou experimentovat' i s vlastnou nomádskou identitou a práve vd'aka tomu sa mu podarilo dosiahnut' jedinečnú reprezentáciu mýtickej duality profánneho a sakrálneho.

Ešte korporeálnejšie splynul hlas s gestom v opere Johna Zorna Astronóm (Astronome; 2006). Dielo je úplne bez slov. Namiesto nich v ňom účinkuje jazyk - praorálny jazyk, akým so svetom, prirodzeným i nadprirodzeným, oddávna komunikujú mýtické orákulá, ezoterickí evokátori a zaklínači, magickí alchymisti, orientálni mystici, „krutí “ performeri a fónickí básnici. Totálny jazyk preverbálnych gest. Kryptický jazyk, aký sa nezabúda! Spevák Mike Patton, ktorého Zorn obsadil do hlavnej úlohy, ním hovorí naproste plynne a zrozumitel'ne. Vo frenetickom tanci neverbálnych vokálno-gestických performancií ekvilibristicky balansuje na hranici medzi jazzovou vokalízou a noisovým laryngálnym beštiáriom a zároveň exhibicionisticky vystavuje na obdiv barthesovské zrno vlastných hlasov (má ich totiž niekol'ko). Zorn Pattonovho génia nielen pochopil, ale aj stimuloval. V Astronómovi poslal jeho hlas do priestoru beyovskej ontológie chaosu - mimo dosah „hermetalingvistiky“ i „,nihilistickej lingvistiky“, t.j. do priestoru „bez ,pána 'jazyka, bez kategorických imperativov, bez determinizmu, bez zjavenia ,zvonka' či ,zhora', bez genetického kódovania, bez absolútnej podstaty." Pattonov hlas i prejav sú skutočne archetypálne. Je to šaman a trickster zároveň. Človek má sklon verit' všetkému, čo sa mu živelne derie z hrdla, a ignorovat' diskurzívne spôsoby artikulácie.

Namiesto konvenčného scénického libreta Zorn poskytol sloganovitý popis scén a akcií, sprevádzaný sériou čiernobielych, mysteriózne ladených fotografií Scotta Izbina. Sú to skôr indície než inštrukcie. Pridal aj verbálne a obrazové komentáre, z ktorých si poslucháč urobí predstavu o poetike a inšpiračných zdrojoch diela. Okrem iného sa dozvie, že vzniklo vlastne na neformálnu objednávku od avantgardného divadelníka Richarda Foremana, v čase, ked’ sa práve jeho autor po rokoch znovu zaoberal textami Antonina Artauda a Edgarda Varèsa, čo sa premietlo do námetu i kompozičného procesu. Dalo by sa povedat', že divadelník Artaud a hudobník Varèse sa znovu stretli v Zornovej mysli a vnukli mu myšlienku dokončit’ za nich to, čo oni sami nestihli - projekt „krutej“ hudby.

6 BEY, Hakim. T.A.Z. The Temporary Autonomous Zone, Ontological Anarchy, Poetic Terrorism. New York: Autonomedia, 2003, s. 135.

7 Na prelome 20. a 30. rokov minulého storočia Varèse pracoval na opere L'Astronome, ktorú však nikdy nedokončil; o pár rokov neskôr mu Artaud napísal text Il n'ya plus de firmament ako libreto k zamýšl’anému, no tiež nerealizovanému oratóriu. 
Nad týmto virtuálnym stretnutím sa vznáša, ako všade a vždy prítomná chiméra, duch Aleistera Crowleyho (a chvíl'ami aj Alejandra Jodorowského), bez odkazu ktorého by Astronóm sotva uzrel svetlo i tmu reálneho sveta.

Na operu je Astronóm pomerne krátky; vo zvukovej podobe trvá asi 45 minút, v jedinej dosial jestvujúcej scénickej asi hodinu. Je to komorné dielo (autor ho nazýva „vreckovou operou“) nielen čo do obsadenia, scény a dížky, ale predovšetkým vd’aka intímnej „vnútrajškovosti“ celkovej nálady. Má tri dejstvá a sedem scén so situačnými názvami: Odl'ahlá čistinka v lesoch, Jednoduchá postel' $v$ malej miestnosti, Kaplnka uprostred tajného chrámu, Stredoveké laboratórium, $V$ magickom kruhu, Holá pláň o polnoci a Nemenovaná lokalita. Ked’že v opere účinkuje len jediný spevák, nie sú v nej žiadne dialógy, iba jeden dlhočizný monológ. Vlastne to ani nie je monológ, skôr trojjediný hudobný orga(ni)zmus, riadiaci sa živelným a súčasne životodarným vokálnym prejavom. Napriek tomu, nemožno povedat', že by v nej úplne absentoval príbeh. Podobne ako Partchovo Delusion, aj ona je naratívna, no nie konvenčným spôsobom. Je to akýsi zvukový výlet do sveta nadčasovej mystiky s mnohými epizódami, ktoré však nemožno verbalizovat' diskurzívnym jazykom, možno ich postihnút' iba intuitívne a transcendentálne, s pomocou audio-mimetických nástrojov. A tie Zorn vždy ovládal majstrovsky. Nie je to amorfný noisový chaos, ako by sa na prvé počutie mohlo zdat', ale precízne komponovaný a rytmizovaný chaozmos. V podstate je ale na každom poslucháčovi (alebo potenciálnom inscenátorovi), ako si tento chaoidný prúd zvukov sám vo svojej mysli (alebo na scéne) zanimuje.

Ťažko si predstavit' inú scénu, kde by Astronóma uviedli tak, aby neutrpel režisérskymi a scénografickými zásahmi, než je Ontologicko-Hysterické divadlo Richarda Foremana v newyorskej East Village, kde mal, v Kostole Sv. Marka, vo februári 2009 premiéru. ${ }^{8}$ Nakoniec, „opera vo vokalíze“ bol Foremanov nápad, hoci si zrejme výsledok svojej objednávky predstavoval celkom inak. Neuspokojil sa totiž s tým, čo od skladatel'a dostal, a vo svojej inscenácii pridal k hudbe slová - zaklínacie formulky, rečnícke otázky a kratučké monológy. Inak sa ale dost' striktne pridržiaval scénických obrazov a akcií z pôvodného libreta. Operu inscenoval v obsadení pre sedem hereckých charakterov, tri ženské a štyri mužské. Ako všetky jeho inscenácie, aj táto je vel'mi spektakulárna, je to guláš rítov, symbolov, textových fragmentov a rekvizít. Klaustrofóbicky stiesnený box, kde sa odohráva, pripomína väčšmi než stredoveké alchymické laboratórium či mýtoetymologickú svätyňu, aké by mal v ezoterickom duchu libreta reprezentovat', kabinet kuriozít alebo bizarný rekvizitár. Postavy, navlečené do prazvláštnych kostýmov, kombinujúcich slovanské folklórne prvky so židovskou, islamskou i vymyslenou ikonografiou, $v$ ňom predvádzajú sled mátožných performancií, v ktorých mnohorakými spôsobmi neustále predstierajú oddel'ovanie a zjednocovanie tela a ducha. Ohlušujúcu hudbu si viac-menej nevšímajú, reagujú na ňu len sporadicky, no prekvapujúco presne. Že by zámer ešte viac dezorientovat' už i tak na DVD pod názvom Astronome: A Night at the Opera (New York: Tzadik, 2010). 
dost' zmätené publikum, príznačný pre nereprezentatívnu poetiku Foremanovho totálneho divadla? V exorcistickom dance macabre mentálnych i telesných kŕčov režisér zosynchronizoval pôvodnú hudbu s divadelnou akciou, no nechal ju, mierne upravenú, zniet' z reproduktorov, čím stratila charakter živej „spevohry“ a zmenila sa na scénický sprievod.

Vysvetlenie pre bizarnú kombináciu teatrálnej absurdity a krutosti s rockovo-noisovo-punkovou agresivitou asi najlepšie sformuloval sám Foreman v záverečnom obraze-dialógu: „A on vraví: ,Rozumieš prečo muži a ženy stratili schopnost' konfrontácie s istými nepreniknutelnými objektmi?' A ona vraví: ,Možno hudba, hudba, hudba... "“ Čo hudba, to sa už divák-poslucháč nedozvie, no nech tým už myslel čokol'vek, Astronóm je nesporne jedno z najzaujímavejších hudobno-dramatických diel od čias Partchovho korporeálneho rituálu Delusion of the Fury. A možno je aj alibistickou, v každom prípade však svojskou odpoved’ou na otázku, či vôbec môže pri všeobecnej platnosti postmodernej tézy anything goes existovat' skutočná avantgarda. Odpovede na ňu pozná zrejme len Astronóm.

Jozef Cseres (hermear@hotmail.com) přednáší estetiku a filozofii umění na Filozofické fakultě UK v Bratislavě a Filozofické fakultě MU v Brně. Předmětem jeho vědeckého zájmu jsou strukturální vztahy mezi hudbou a mýtem, umělecká reprezentace a interpretace, experimentální a improvizovaná hudba a intermedia.

\section{ABSTRACT \\ VOICE AND GESTURE IN THE OPERAS BY HARRY PARTCH AND JOHN ZORN.}

The paper deals with the mutual relationships between voice and gesture in the Harry Partch's Delusion of the Fury and John Zorn's Astronome. From the philosophical standpoint it reveals the progressive evolvement of the vocal performance poetics towards a corporeality of voice in current staged intermedia. It also regards the process of ritualization and the way of treatment the mythological subjects in reflected works of art.

Key words

Alvin Lucier, Iannis Xenakis, Harry Partch, John Zorn, Astronome, opera, gesture, voice

\section{Bibliography}

BEY, Hakim. T.A.Z. The Temporary Autonomous Zone, Ontological Anarchy, Poetic Terrorism.

New York: Autonomedia, 2003.

LUCIER, Alvin. Reflections/Reflexionen. Kolín nad Rýnom: MusikTexte, 1995.

PARTCH, Harry. Genesis of a Music. New York: Da Capo Press, 1974.

PARTCH, Harry. Bitter Music. Collected Journals, Essays, Introductions, and Librettos. Urbana/ Chicago: University of Illinois Press, 2000.

XENAKIS, Iannis. Poznámky o elektronickom geste. Slovenský preklad: Vladimír Godár. Slovenská hudba, 1993, 1. 